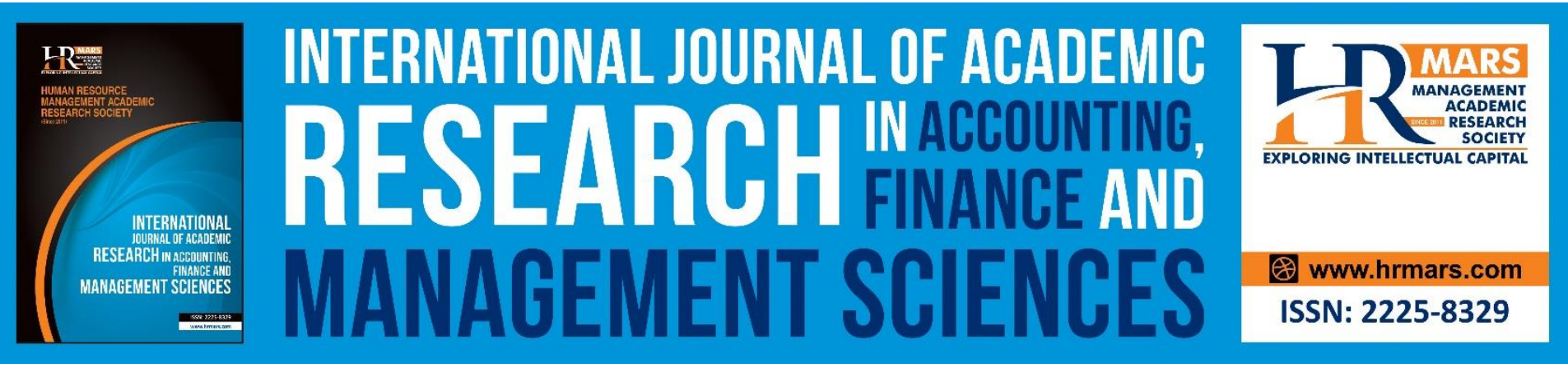

\title{
Sensitivity of Banks' Stock Returns to the Changes in The Market, Interest and Exchange Rates: Evidence from Malaysia
}

Mohamad Azwan Md Isa, Norashikin Ismail, Ruziah A Latif \& Syamsyul Samsudin

To Link this Article: http://dx.doi.org/10.6007/IJARAFMS/v11-i1/8830 DOI:10.6007/IJARAFMS /v11-i1/8830

Received: 20 December 2020, Revised: 23 January 2021, Accepted: 15 February 2021

Published Online: 28 February 2021

In-Text Citation: (Isa et al., 2021)

To Cite this Article: Isa, M. A. M., Ismail, N., Latif, R. A., \& Samsudin, S. (2021). Sensitivity of Banks' Stock Returns to the Changes in The Market, Interest and Exchange Rates: Evidence from Malaysia. International Journal of Academic Research in Accounting Finance and Management Sciences, 11(1), 256-270.

Copyright: (C) 2021 The Author(s)

Published by Human Resource Management Academic Research Society (www.hrmars.com)

This article is published under the Creative Commons Attribution (CC BY 4.0) license. Anyone may reproduce, distribute, translate and create derivative works of this article (for both commercial and non-commercial purposes), subject to full attribution to the original publication and authors. The full terms of this license may be seen at: http://creativecommons.org/licences/by/4.0/legalcode

Vol. 11, No. 1, 2021, Pg. 256 - 270

http://hrmars.com/index.php/pages/detail/IJARAFMS JOURNAL HOMEPAGE

Full Terms \& Conditions of access and use can be found at http://hrmars.com/index.php/pages/detail/publication-ethics 


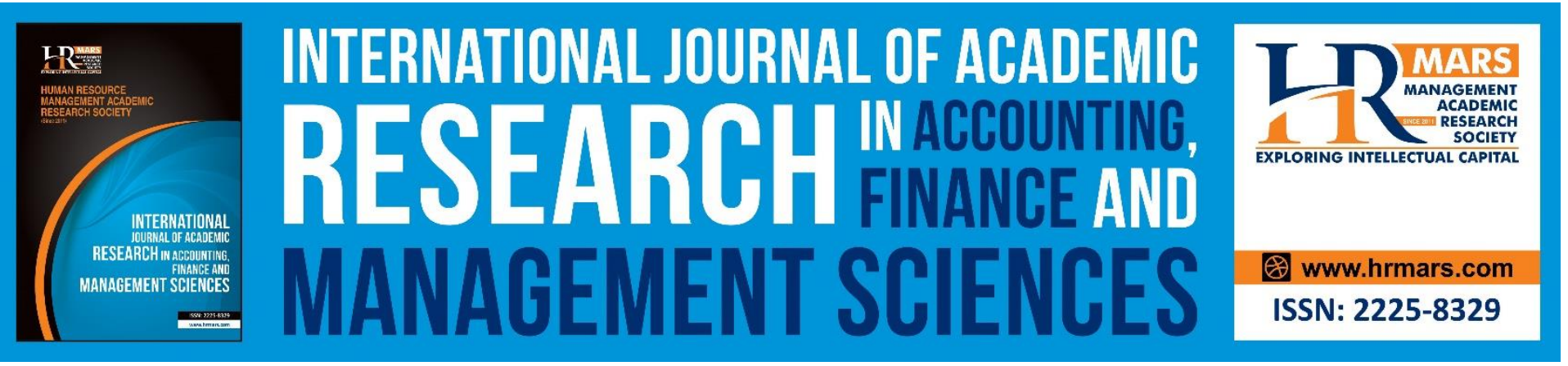

\title{
Sensitivity of Banks' Stock Returns to the Changes in The Market, Interest and Exchange Rates: Evidence from Malaysia
}

\author{
Mohamad Azwan Md Isa, Norashikin Ismail, Ruziah A Latif \& \\ Syamsyul Samsudin \\ Faculty of Business and Management, Universiti Teknologi MARA (UiTM), Johor Branch, Segamat \\ Campus, Malaysia \\ Email: moham821@uitm.edu.my
}

\begin{abstract}
This paper aims to investigate the impacts on banks' stock returns due to changes in interest rate, exchange rate and market returns. This study also aims to examine whether the volatility of stock returns in the past has any impact on the volatility of today's stock returns. The raw data are taken from several sources such as Eikon DataStream and Central Bank of Malaysia website. We test on seven (7) main Malaysian banks' stocks and the Finance Index as a proxy for the bank portfolio, which are listed on the Bursa Malaysia covering daily data from January 2015 to December 2019. We begin with the descriptive statistics analysis and further, we employ Ordinary Least Squares (OLS) estimation to examine the impacts of changes in the economic variables on the bank stocks and portfolio returns. Then, we apply the Generalized Autoregressive Conditional Heteroscedasticity (GARCH 1,1) estimation to determine the relationship between the volatility of stock returns in the past with the volatility of the current. The market return has positive impacts on the portfolio and individual banks stock returns. The portfolio and banks stock returns are found to be more sensitive towards the changes in the market return than the changes in the foreign exchange and interest rates. The GARCH estimation shows the existence of time-varying conditional volatility of the bank stock returns. In addition, there is a prolonged existence of volatility shocks and the volatility reaction decomposes at a moderate pace. The GARCH parameter is significantly larger than the ARCH parameter that proves the volatility of bank stock returns is more sensitive to its own lagged values than to the new shocks. The findings have policy implications either at the banks' management level and policy makers. The stock market investors and academic researchers will also benefit from this study.
\end{abstract}

Keyword: Bank Stock Returns, Economic Variables, Volatility, GARCH, Malaysia 
INTERNATIONAL JOURNAL OF ACADEMIC RESEARCH IN ACCOUNTING, FINANCE AND MANAGEMENT SCIENCES

Vol. 11, No. 1, 2021, E-ISSN: $2225-8329$ @ 2021 HRMARS

\section{Introduction}

Banking institution is the financial intermediary that connects all sectors participates in economic activities. Households use banks' services to save money and perform online transactions, business entities need banks' loans to expand their businesses and the government channels development funds through the banks as well. This indicates how crucial the roles of banks are. Therefore, the banks must be well-functioning and efficient to further support the economic growth. Nevertheless, the banks are also exposed to economic crisis. For example, in the aftermath of the $1997 / 1998$ Asian financial crisis, Malaysian banking sector had faced serious problems that resulted in massive consolidation that witnessed 50 financial institutions were merged to become 10 large banking groups. Moreover, the banks are exposed to many types of risks such as credit risk (default payment by loans customers), market risk (changes in interest rates) and liquidity risk (sudden large withdrawals by depositors) that could be detrimental to the banks' earnings and cash flows.

In the modern economy, the banks are going for public listing. The structure of banks' capital is no longer concentrated on the customers' deposits, but rather moving towards equity capital. As partners in the banks, the equity holders are really concerned on changes in stock prices because it gives significant impact on their stock returns. Among the risk factors that could influence the volatility of stock prices are the changes in interest rate and exchange rate. The volatility of stock price contributes towards volatility in stock return. Thus, this will influence the equity holders' decision either to stay investing or not that ultimately affects banks' sustainability in the future.

Interest rate is an important variable in banks' common stocks valuation because both the returns as well as costs of banks are greatly dependent on interest rates. The banks traditionally rely on customers' deposits as the main source of funds. The customers' deposits, which are granted as loans contribute significantly towards banks' total earnings in the form of interest income. Both deposits and loans are very much prone to changes in the interest rates. Hence, the earnings of the banks are also directly affected by the changes in interest rates. Consequently, this has led to several studies investigating the influence of interest rate on bank stock returns in developed markets (Flannery, 1981; Denenis \& Staikouras, 1998; Priti, 2016) and developing markets (Kasman, Vardar \& Tunc, 2011; Khan and Sattar, 2014).

Exchange rate is another important macroeconomic variable to the banks' stock returns. The banking sector, like any other sectors, is also affected by the growing internationalization of the economy (Choi, Elyasiani \& Kopecky, 1992). Flexible exchange rate regime and rising globalisation of the economy has increased the volatility of exchange rate. This fluctuation would influence banks' net foreign positions and consequently impact their profitability. It is vital to include exchange rate in this study as exchange rate fluctuation could be a potential factor of banks' stock return.

Therefore, by using daily data from seven Malaysian banks from 2015 to 2019, this study aims to investigate the impacts on banks' stock returns and portfolio returns due to changes in interest rates, exchange rate and market return. On top of that, this study also aims to examine whether volatility of the banks' stocks in the past has any impact or influence on the volatility of the stocks in the current time and in the future. This study, to the best of our knowledge as per searches for the previous related literatures or researches, is the latest that combines both tests of the OLS and GARCH model estimations, which relate to the Malaysian banks' stock returns. This study also employs daily closing prices to calculate the stock returns that will give more accurate and pronounced results or estimations compared to the previous studies that used weekly or monthly data. 
INTERNATIONAL JOURNAL OF ACADEMIC RESEARCH IN ACCOUNTING, FINANCE AND MANAGEMENT SCIENCES

Vol. 11, No. 1, 2021, E-ISSN: 2225-8329 @ 2021 HRMARS

The findings of this study are significant in assisting the banks' management in mitigating the risk exposures due to changes in interest rate and exchange rate either through assets and liabilities matching approach or applying hedging strategies in the derivatives market using interest rate futures and currency futures or swaps. The study will also benefit the policy makers such as the Bank Negara Malaysia (BNM) and Securities Commission (SC) to come up with appropriate measures in the matters pertaining to the risk-based bank capital requirement, sustainability of banks' stocks in the capital market and stability of financial system in Malaysia as a whole. Besides, the findings of study will signal the policy makers to be more aware in formulating any policies pertaining to the economic variables that act as the risk factors, which could affect the banks' stock returns adversely and significantly. Investors in the stock market will benefit from this study as the findings could assist them in assessing the risks and making investment decision particularly in setting the best portfolio investment mix.

The remainder of this paper is organized as follows; next Section 2 presents the literature review while Section 3 explains the data and methodology, Section 4 discusses the empirical results and findings, finally Section 5 provides the conclusions.

\section{Review of Literature}

The studies related to the banks stock returns have been getting more attention and interest by researchers particularly in the aftermath of the financial crisis in 1997/1998. Those studies used several different methodologies and basis of data that give rise to distinct empirical findings. Benink and Wolff (2000) employ weekly data of the twenty largest US bank holding companies for the period 1974-1993 and use the forecast errors of ARIMA processes to model the unexpected interest rate. They evidence significant negative interest rate sensitivity during the early 1980 s and declining significance in the late 1980s and early 1990s. Their results further show a breakdown of the statistically significant interest rate sensitivity of US bank stock returns during the second half of the 1980s. Fraser, Madura and Weigand (2002) find a significantly negative relation between bank stock returns and changes in interest rates. They also find that bank characteristics measured from basic financial statement information explain bank stocks' sensitivity to interest rate changes. Meanwhile in Japan, Saporoschenko (2002) indicates that bank stock returns are significantly and negatively related to long-term interest rate shocks. Market betas are found to be always highly significant while few of the exchange rate return betas and interest rate spread betas are significant.

Elyasiani and Mansur (2004) study the US banks' stocks traded at the New York and NASDAQ Stock Exchanges from 1988 to 2000 using the multivariate GARCH approach. They state that short term and long term interest rates and both rates volatilities pose significant impacts on banks' portfolio stock returns. They further claim that banks' stocks are more sensitive towards or more affected by the long term interest rate. This means that the banks' stock returns volatility increases as a result of increased volatility in long term interest rate. Another study by Elyasiani and Mansur (2005) on the Japanese banking institutions indicate that interest rate is only occasionally significant while market and exchange rate variables are significant for all the banks tested. Hooy, Tan and Nassir (2004) examine the sensitivity of Malaysian commercial banks' stock excess returns to their volatility and financial risk factors, measured by interest rates and exchange rates, across the 1997/1998 Asian financial crisis. They prove that that there were no significant differences among the commercial banks in their risk exposure prior to and during the Asian financial crisis. The effects of the risk factors on the banks' stock returns were significantly detected in both large and small banks. 
INTERNATIONAL JOURNAL OF ACADEMIC RESEARCH IN ACCOUNTING, FINANCE AND MANAGEMENT SCIENCES

Vol. 11, No. 1, 2021, E-ISSN: 2225-8329 @ 2021 HRMARS

Another study related to the US banks by Joseph and Vezos (2006) conclude that the market index returns account for most of the variation in stock returns at both the individual bank and portfolio levels. They further add that the degree of sensitivity of the stock returns to interest rate and exchange rate changes is not very noticeable despite the use of high frequency data. Using publicly listed Australian banks data, Shamsuddin (2009) estimates the systematic risk exposure with respect to the market, interest rate and foreign exchange rate using GARCH-in-Mean model. The results suggest that nearly all banks demonstrate varying degrees of market risk exposure. Nevertheless, stock returns of large banks are highly sensitive to interest rate changes, whereas most small banks are almost unaffected by both interest rate and exchange rate changes.

Using the multivariate OLS and GARCH estimation models over the period from April 1996 to March 2011 on the sample of 18 commercial bank stocks listed on Bombay stock exchange, Tripathi and Ghosh (2012) find a negative but insignificant relationship between Bank stock returns and interest rate changes. The bank stock returns show significant positive relationship with the market returns. Nevertheless, interest rate volatility is found to affect significantly the banks stock returns volatility in India. In Turkey, Kasman et al. (2011) investigate the impact of interest rate and exchange rate volatility on banks' stock returns and the results prove that banks' stock returns are negatively and significantly affected by the changes in both economic variables. Further, they evidence that volatility of interest rate and exchange rate are the major determinants for volatility of banks' stock returns. Moreover, they suggest that banks' stock returns are more sensitive to changes in market return than the interest rate and exchange rate.

Khan and Mahmood (2013) investigate the sensitivity of interest rate to stock return of 29 financial institutions traded at Karachi Stock Exchange from 2004 to 2011 using three different portfolios of financial institutions. They conclude that stock returns of financial institution demonstrate positive sensitivity to market index and are statistically significant. Nevertheless, stock returns sensitivity to interest rate is negative and statistically insignificant. Jeanchutima and Tangjitprom (2015) reveal mixed results in Thailand, where the effect of interest rate level is prominent on only a few individual bank stocks and most of them are large-sized banks. In addition, the results from portfolio of bank stocks show significant effect of interest rate does exist only for the portfolio of large banks. However, there is no interest rate effect on the portfolio of small banks or the portfolio with companies running the similar business as commercial banks. Mouna and Anis (2016) investigate the sensitivity of financial sector stock returns to market, interest rate, and exchange rate risk in in eight countries, including various European, the US, and China economies, over the period 2006-2009 during the financial crisis. The findings reveal that there are statistically significant with a positive or a negative effect from the exchange rate of the volatility short-term interest rate, long-term interest rate and stock returns to the banking sector and volatility spill-overs from market returns.

Lee, Kuo and Lee (2018) address the exposure of banking industry stock returns to both the commercial and residential real estate markets in the US. They found that banking industry stock returns are significantly sensitive to real estate market returns after controlling for stock market, interest rate, and exchange rate effects. Another study testing on the Listed Banks of Pakistan by Rafiq, Jun, Naseem and Mohsin (2019) using time series data from 2007 to 2018 reveal that the market return (proxy by the KSE-100 index) pose positive significant, exchange rate (proxy by USD/PKR) has negative significant, and the interest rate (proxy by 3-month treasury bill rate) indicates insignificant impact, respectively on the bank stock returns. Meanwhile, a study by Martina, Sadalia 
INTERNATIONAL JOURNAL OF ACADEMIC RESEARCH IN ACCOUNTING, FINANCE AND MANAGEMENT SCIENCES

Vol. 11, No. 1, 2021, E-ISSN: 2225-8329 @ 2021 HRMARS

and Bukit (2019) examine 23 banking companies listed on the Indonesia Stock Exchange from 2008 to 2017 and conclude that liquidity, leverage and profitability factors significantly affect banks' stock returns with profitability ratios pose positive significant impact on banks' stock returns whilst liquidity and leverage ratios have negative but insignificant impact on the bank stock returns.

\section{Data and Methodology}

In this paper, we examine the impact on bank's stock return due to changes in interest rate, exchange rate and market return. Initially, we have selected all the ten (10) Malaysian local banks that are listed on the Bursa Malaysia or stock exchange. However, three of the banks, namely Maybank, Alliance Bank and Hong Leong Finance had to be deselected due to incomplete or unavailability of continuous daily data. Following Kasman et al. (2011) and Mouna et al. (2016), the daily closing individual bank stock price, the closing price of the Finance index, interest rates and exchange rates are used for the period of 5 years starting from January 2015 to December 2019. In addition, the closing price of the FTSE BM KLCl index is used for the market index.

The interest rates comprise short, medium and long terms rates, where the interbank rate is proxy for the short-term rate, the 3-year bond yield is proxy for medium-term rate and the 10-year bond yield is proxy for the long-term rate. The foreign exchange rate is based on the Malaysian ringgit (MYR) to the U.S. dollar (USD). The selection of exchange rate, interest rate and stock return on the financial sector is based on Aloui and Jarboui $(2013,2016)$ and Ryan and Worthington (2004). Tables 1 presents the list of seven banks including the Finance Index as the dependent variables and Table 2 details the independent variables tested in this study.

Table 1. List of Seven Malaysian Banks

\begin{tabular}{|l|c|}
\hline Dependent Variables & Source of Data \\
\hline Finance Index (Portfolio) & Eikon Datastream \\
\hline Affin Bank Berhad & Investing.com \\
\hline AMMB Holdings Berhad & Yahoo Finance \\
\hline BIMB Holdings Berhad & Investing.com \\
\hline CIMB Group Holdings Berhad & Yahoo Finance \\
\hline Hong Leong Bank Berhad & Yahoo Finance \\
\hline Public Bank Berhad & Yahoo Finance \\
\hline RHB Bank Berhad & Yahoo Finance \\
\hline
\end{tabular}


INTERNATIONAL JOURNAL OF ACADEMIC RESEARCH IN ACCOUNTING, FINANCE AND MANAGEMENT SCIENCES

Vol. 11, No. 1, 2021, E-ISSN: 2225-8329 @ 2021 HRMARS

Table 2. Independent Variables

\begin{tabular}{|c|c|c|}
\hline $\begin{array}{l}\text { Independent } \\
\text { Variables }\end{array}$ & Description (Proxy for/by) & Source of Data \\
\hline FBM KLCl & $\begin{array}{l}\text { Market or economic-wide } \\
\text { factors }\end{array}$ & $\begin{array}{c}\text { Eikon } \\
\text { Datastream }\end{array}$ \\
\hline $\begin{array}{l}\text { Foreign exchange } \\
\text { rate }\end{array}$ & Bid price of MYR/USD & $\begin{array}{c}\text { Eikon } \\
\text { Datastream }\end{array}$ \\
\hline $\begin{array}{l}\text { Short term interest } \\
\text { rate }\end{array}$ & Overnight interbank rates & BNM \\
\hline $\begin{array}{l}\text { Medium term } \\
\text { interest rate }\end{array}$ & Malaysia 3-year bond yield & Investing.com \\
\hline $\begin{array}{l}\text { Long term interest } \\
\text { rate }\end{array}$ & Malaysia 10-year bond yield & Investing.com \\
\hline
\end{tabular}

The daily returns $\left(r_{t}\right)$ for the stocks are computed as follows:

$r_{t}=\left[\left(p_{t}-p_{t-1}\right) / p_{t-1}\right]^{*} 100 \%$

Where $p_{t}$ is stock price at time $t$ and $p_{t-1}$ is the stock price at time $t-1$.

This study applies descriptive statistics to analyze the banks' stock return distribution that includes the mean return, skewness and kurtosis. Similar to Aloui and Jarboui (2013), we employ the OLS and GARCH estimation. The OLS method is used to estimate the impacts of changes in interest rates, exchange rate and the market returns on the banks' stock and portfolio returns. The estimated OLS model is stated as follows:

$r_{t}=B_{0}+B_{1} M K T_{t}+B_{2} I N T_{t}+B_{3} E X C_{t}+\varepsilon_{t}$

Where $r_{t}$ is the bank's stock and portfolio returns, respectively and at time $t ; M K T_{t}$ is the return on the market that also represents the economy-wide factors; $I N T_{t}$ is the return on the short, medium and long terms interest rates, respectively; and $E X C_{t}$ is the return on the foreign exchange rate. $B_{0}$ is the intercept or constant and $\varepsilon_{t}$ is the error term or residual. Then, we use the $\operatorname{GARCH}(1,1)$ estimation to examine whether the volatility of the stocks in the past has any impact on the current volatility of the stocks. Subsequently, we would able to predict the stock volatility in the future. The GARCH $(1,1)$ model is stated as below:

$r_{t}=\omega+\pi_{1} r_{t-1}+\varepsilon_{t}$

$\sigma^{2}$

${ }_{t}=\alpha_{0}+\alpha_{1} \varepsilon^{2}{ }_{t-1}+b \sigma^{2}{ }_{t-1}$

Where $\omega$ represents constant or average stock return and $r_{t-1}$ represents the past value of the stock, $\pi$ is the coefficient and $\varepsilon_{t}$ is the error term. The variance equation (4) encompasses the longterm average volatility $\left(\alpha_{0}\right)$, news about volatility from the prior period that is explained as the $A R C H$ term $\left(\varepsilon^{2} t-1\right)$, and the prior period's forecast variance that is described as the GARCH term $\left(\sigma^{2}{ }_{t-1}\right)$. The GARCH specification entails that in the conditional variance equation, parameters or coefficients $\alpha_{0}$, 
INTERNATIONAL JOURNAL OF ACADEMIC RESEARCH IN ACCOUNTING, FINANCE AND

MANAGEMENT SCIENCES

Vol. 11, No. 1, 2021, E-ISSN: 2225-8329 @ 2021 HRMARS

$\alpha_{1}$ and $B$ should be positive for a non-negativity condition. In addition, the sum of $\alpha_{1}$ and $B$ should be less than ' 1.0 ' to secure the covariance stationarity of the conditional variance. All the aforementioned tests will be run using the EViews 10 software with the courtesy of the IT Unit of UiTM Johor Branch.

\section{Empirical Results and Discussion}

Descriptive Statistics

The following Table 3 summarizes the descriptive statistics for the finance index (portfolio) and individual bank stock returns.

Table 3. Descriptive Statistics of Dependent Variables

\begin{tabular}{|l|c|c|c|c|c|c|c|c|}
\hline Variable & RFIN & RPUB & RHLB & RRHB & RAFF & RAMB & RISL & RCIM \\
\hline Mean & 0.0021 & 0.0071 & 0.0227 & -0.0056 & -0.0224 & -0.0339 & 0.0175 & 0.0063 \\
\hline Max. & 2.3846 & 4.6392 & 11.1111 & 16.8224 & 8.5308 & 13.3630 & 5.5421 & 16.9117 \\
\hline Min. & -3.2317 & -3.6948 & -4.8235 & -20.6557 & -6.6371 & -36.7816 & -7.1633 & -13.1914 \\
\hline Std. Dev. & 0.6031 & 0.6663 & 0.9368 & 1.5525 & 1.1692 & 1.5901 & 1.3331 & 1.5557 \\
\hline Skewness & -0.3814 & 0.0726 & 1.4304 & -1.0738 & 0.7617 & -9.7422 & 0.0823 & 1.0674 \\
\hline Kurtosis & 5.8313 & 11.6823 & 21.9337 & 44.1722 & 10.1511 & 241.2294 & 4.5604 & 25.2972 \\
\hline
\end{tabular}

The bank portfolio shows a low positive mean daily return whilst the individual bank indicates Hong Leong Bank has the highest positive average daily stock return throughout the sample period whilst AmBank shows the lowest and negative average daily return. CIMB records the highest daily return and followed by $\mathrm{RHB}$ at almost $17 \%$, respectively. Meanwhile, AmBank records the lowest daily return at $-36 \%$ and followed by $\mathrm{RHB},-20 \%$. In term of data dispersion, AmBank stock return is the most spread out from its mean return and followed CIMB and RHB. The lowest dispersion is recorded by the portfolio return and Public Bank at $0.6 \%$ from the mean return, respectively. For measurement of data normality, we found that all the return data series are leptokurtic with positive values more than 3, where AmBank shows the highest peak-curved while Bank Islam (BIMB) has the lowest peak-curved. In term of data series asymmetry, we could see that Public Bank and BIMB have normal skewness with the value of close to 0 , respectively, whereas AmBank has the largest negative skewness compared to RHB. The portfolio return series show a slight negative skewness or long left tail.

Table 4. Descriptive Statistics of Independent Variables

\begin{tabular}{|l|c|c|c|c|c|}
\hline Variable & RMKT & REXC & RINTLT & RINTMT & RINTST \\
\hline Mean & -0.0051 & 0.0151 & 0.0006 & -0.0083 & 0.0010 \\
\hline Maximum & 2.2468 & 2.0466 & 6.8062 & 6.8365 & 5.6667 \\
\hline Minimum & -3.1849 & -3.5910 & -3.3813 & -4.0910 & -4.8859 \\
\hline Std. Dev. & 0.5672 & 0.4397 & 0.6150 & 0.6239 & 0.6386 \\
\hline Skewness & -0.3647 & -0.5962 & 0.9908 & 1.8448 & 0.2323 \\
\hline Kurtosis & 5.3905 & 10.3107 & 20.1819 & 31.1602 & 15.2959 \\
\hline
\end{tabular}

For the independent variables, market index and mid-term interest rate have shown negative mean daily return whilst foreign exchange and short- and long-term interest rates record very low positive mean return. Long-term interest rate proxy by 10 -year bond yield and mid-term interest rate 
INTERNATIONAL JOURNAL OF ACADEMIC RESEARCH IN ACCOUNTING, FINANCE AND MANAGEMENT SCIENCES

Vol. 11, No. 1, 2021, E-ISSN: 2225-8329 @ 2021 HRMARS

proxy by 3-year bond yield indicate the highest daily return, close to $7 \%$, respectively. The short-term interest rate proxy by the interbank rate has the lowest return roughly $-5 \%$. The series for short- and mid-term interests are the most spread out from mean return, respectively. All the return series are found to be leptokurtic, where the mid-term interest rate has the highest peak curve with largest positive skewness or long right tail and followed by the long-term interest rate.

\section{Estimation with OLS Models}

Table 5 presents the results of the OLS estimation.

Table 5. OLS Estimation of Bank Portfolio and Individual Banks

\begin{tabular}{|l|c|c|c|c|c|c|c|}
\hline Variables & $\begin{array}{c}\mathbf{C} \\
\left(\boldsymbol{B}_{\mathbf{0}}\right)\end{array}$ & $\begin{array}{c}\text { RMKT } \\
\left(\boldsymbol{B}_{\mathbf{1}}\right)\end{array}$ & $\begin{array}{c}\text { REXC } \\
\left(\boldsymbol{B}_{\mathbf{2}}\right)\end{array}$ & $\begin{array}{c}\text { RINTLT } \\
\left(\boldsymbol{B}_{\mathbf{3}}\right)\end{array}$ & $\begin{array}{c}\text { RINTMT } \\
\left(\boldsymbol{B}_{\mathbf{4}}\right)\end{array}$ & $\begin{array}{c}\text { RINTST } \\
\left(\boldsymbol{B}_{5}\right)\end{array}$ & $\begin{array}{c}\text { Durbin- } \\
\text { Watson stat. }\end{array}$ \\
\hline RFIN & 0.0067 & 0.9045 & -0.0155 & 0.0117 & -0.0201 & 0.0166 & 2.0615 \\
& $(0.4627)$ & $(0.0000)^{*}$ & $(0.4517)$ & $(0.4261)$ & $(0.1657)$ & $(0.2413)$ & \\
\hline RPUB & 0.0085 & 0.2620 & 0.0104 & -0.0298 & 0.0258 & -0.0254 & 2.1022 \\
& $(0.6470)$ & $(0.0000)^{*}$ & $(0.8046)$ & $(0.3243)$ & $(0.3870)$ & $(0.3840)$ & \\
\hline RHLB & 0.0253 & 0.3293 & -0.0775 & -0.0390 & -0.0187 & 0.0638 & 2.3074 \\
& $(0.3357)$ & $(0.0000)^{*}$ & $(0.1948)$ & $(0.3620)$ & $(0.6569)$ & $(0.1219)$ & \\
\hline RRHB & -0.0031 & 0.4065 & -0.0133 & -0.0524 & 0.02880 & 0.0349 & 2.3236 \\
& $(0.9433)$ & $(0.0000)^{*}$ & $(0.8937)$ & $(0.4648)$ & $(0.6823)$ & $(0.6126)$ & \\
\hline RAFF & -0.0185 & 0.0915 & -0.2230 & 0.0669 & 0.0206 & 0.0146 & 2.2671 \\
& $(0.5795)$ & $(0.1201)$ & $(0.0034)^{*}$ & $(0.2180)$ & $(0.6994)$ & $(0.7795)$ & \\
\hline RAMB & -0.0362 & -0.0744 & 0.0875 & 0.0621 & -0.0439 & 0.1054 & 2.1098 \\
& $(0.4268)$ & $(0.3543)$ & $(0.3983)$ & $(0.4023)$ & $(0.5472)$ & $(0.1402)$ & \\
\hline RISL & 0.0177 & 0.0604 & 0.0194 & 0.0131 & 0.0241 & -0.0852 & 2.4980 \\
& $(0.6415)$ & $(0.3700)$ & $(0.8227)$ & $(0.8323)$ & $(0.6928)$ & $(0.1552)$ & \\
\hline RCIM & 0.0080 & 0.6028 & 0.0874 & -0.0314 & -0.0098 & -0.0040 & 2.2605 \\
& $(0.8540)$ & $(0.0000)^{*}$ & $(0.3774)$ & $(0.6576)$ & $(0.8882)$ & $(0.9529)$ & \\
\hline
\end{tabular}

The market return has positive impact on the portfolio and all individual banks stock returns except for AmBank. Furthermore, the market return is also statistically significant for the portfolio and four individual banks stock returns, namely Public Bank, Hong Leong Bank, RHB and CIMB. We also found that the market return explains a larger portion of portfolio and individual banks stock returns compared to foreign exchange rate and interest rates returns. This means the portfolio and banks stock returns are more sensitive towards the changes in the market or economic-wide factors than the changes in the foreign exchange and interest rates.

Meanwhile, the foreign exchange rate returns are found to be statistically significant only on the Affin Bank stock returns with negative impact. Despite its insignificance, foreign exchange rate returns also pose negative impacts on the bank portfolio returns, Hong Leong Bank and RHB whilst it has positive impact on the rest of banks stock returns. Generally, we notice that the impact of foreign exchange rate returns are stronger on the banks stocks returns compared to the impacts of interest rates returns. This implies that the banks stock returns are more sensitive towards the changes in foreign exchange rates than the interest rates. 
Vol. 11, No. 1, 2021, E-ISSN: 2225-8329 @ 2021 HRMARS

The interest rates returns are found not statistically significant on the bank portfolio and individual stock returns and the impacts of the three types of interest rates returns are mixed on the bank portfolio and individual stock returns in terms of their negativity or positivity impacts and the magnitude of impacts. The last column of Table 5 evidences that the OLS estimation has no residual serial correlation problem based on the Durbin-Watson statistics that range between 1.7 to 2.3. In other words, the absence of residual autocorrelation implies that the OLS coefficients are efficiently estimated.

\section{Volatility Cluster Range}
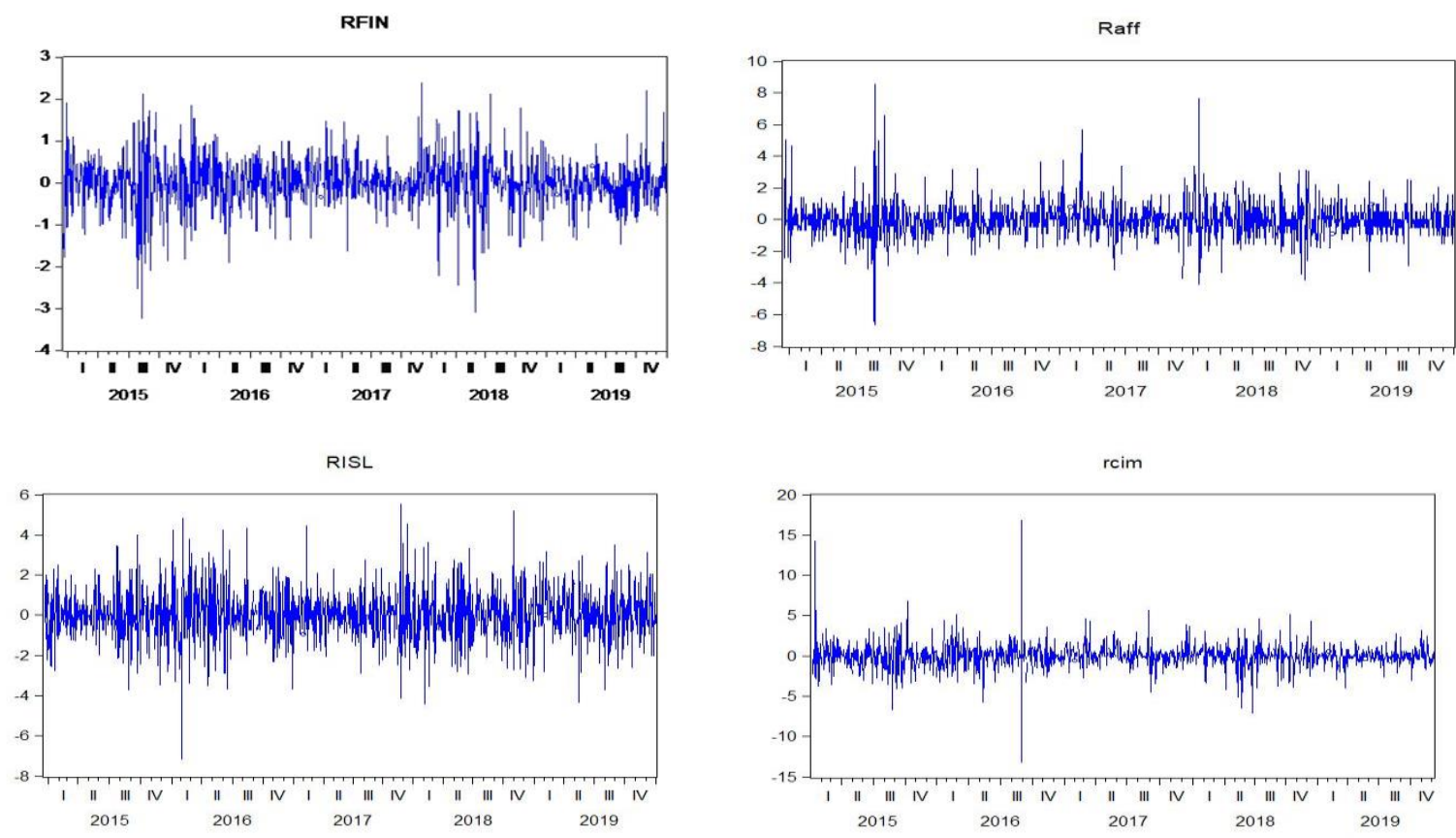
INTERNATIONAL JOURNAL OF ACADEMIC RESEARCH IN ACCOUNTING, FINANCE AND MANAGEMENT SCIENCES

Vol. 11, No. 1, 2021, E-ISSN: 2225-8329 @ 2021 HRMARS
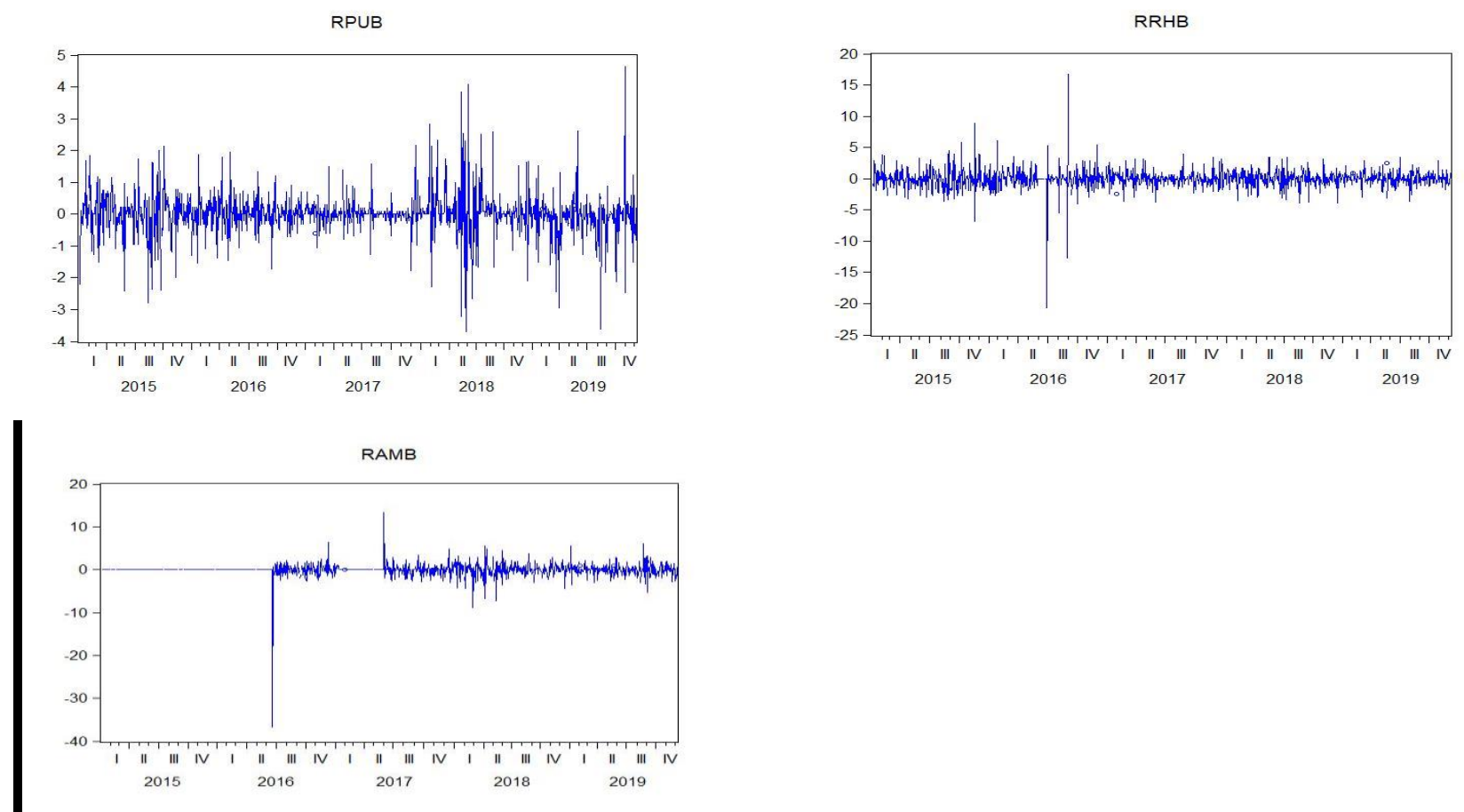

From the above graphs, we can see the evidences that for a period with large changes, it is followed by another period with large changes as well. On the other way around, a period with small changes, it is followed by another period with small changes. From the graphs, bank portfolio and Bank Islam's stock returns show the largest volatility followed by Public Bank and Affin Bank. Meanwhile, $\mathrm{CIMB}, \mathrm{RHB}$ and Hong Leong Bank indicate moderate volatility in their respective stock returns. The stock return of AmBank has shown very slight volatility. 
INTERNATIONAL JOURNAL OF ACADEMIC RESEARCH IN ACCOUNTING, FINANCE AND MANAGEMENT SCIENCES

Vol. 11, No. 1, 2021, E-ISSN: 2225-8329 @ 2021 HRMARS

\section{Estimation with GARCH $(1,1)$ Models}

We test GARCH $(1,1)$ model using the optimization method of Eviews legacy and the error distribution of normal (Gaussian). Table 6 tabulates the results on the GARCH $(1,1)$ estimation.

Table 6. GARCH $(1,1)$ Estimations

\begin{tabular}{|l|c|c|c|c|}
\hline $\begin{array}{l}\text { Dependent } \\
\text { Variable }\end{array}$ & $\begin{array}{c}\text { C } \\
\text { coefficient } \\
(\boldsymbol{p} \text {-value) }\end{array}$ & $\begin{array}{c}\mathbf{r}_{\mathbf{i}}(-\mathbf{1}) \\
\text { coefficient } \\
(\boldsymbol{p} \text {-value) }\end{array}$ & $\begin{array}{c}\text { Resid. (-1) } \\
\text { coefficient, } \boldsymbol{\alpha 1} \\
(\boldsymbol{p} \text {-value) }\end{array}$ & $\begin{array}{c}\text { GARCH (-1) } \\
\text { coefficient, } \boldsymbol{b} \\
\text { ( } \boldsymbol{p} \text {-value) }\end{array}$ \\
\hline RFIN & -0.0011 & $\begin{array}{c}0.0707 \\
(0.9413)\end{array}$ & $\begin{array}{c}0.1419 \\
(0.0237)^{* *}\end{array}$ & $\begin{array}{c}0.7727) \\
(0.0000)^{*}\end{array}$ \\
\hline RAFF & -0.0469 & -0.1563 & 0.1275 & 0.8070 \\
& $(0.0984)^{* * *}$ & $(0.0000)^{*}$ & $(0.0000)^{*}$ & $(0.0000)^{*}$ \\
\hline RAMB & -0.0657 & -0.0319 & -0.0029 & 0.5939 \\
& $(0.4713)$ & $(0.1312)$ & $(0.5428)$ & $(0.2484)$ \\
\hline RISL & 0.0434 & -0.2652 & 0.0889 & 0.8708 \\
& $(0.1934)$ & $(0.0000)^{*}$ & $(0.0000)^{*}$ & $(0.0000)^{*}$ \\
\hline RCIM & 0.0054 & -0.0324 & 0.0624 & 0.8703 \\
& $(0.8917)$ & $(0.3031)$ & $(0.0000)^{*}$ & $(0.0000)^{*}$ \\
\hline RHLB & 0.0074 & -0.1205 & 0.2739 & 0.5069 \\
& $(0.7537)$ & $(0.0050)^{*}$ & $(0.0000)^{*}$ & $(0.0000)^{*}$ \\
\hline RRHB & -0.0198 & -0.0633 & 0.1678 & 0.0586 \\
& $(0.6790)$ & $(0.0886)^{* * *}$ & $(0.0000)^{*}$ & $(0.1813)$ \\
\hline RPUB & -0.0106 & 0.0119 & 0.4531 & 0.5376 \\
& $(0.4703)$ & $(0.7112)$ & $(0.0000)^{*}$ & $(0.0000)^{*}$ \\
\hline
\end{tabular}

*Significance at $1 \%$ level

**Significance at $5 \%$ level

$* * *$ Significance at $10 \%$ level

The average stock return that is denoted by the $\mathrm{C}$ coefficient reveals mixed results on the bank portfolio and individual banks stock returns volatility. The average stock return is only found significant with the Affin Bank stock return volatility. The $r_{i}(-1)$ that denotes the past value of the stock significantly predicts the current value for 5 cases comprising the bank portfolio and four individual bank stock returns. This finding clearly shows that there is existence of time-varying conditional volatility of the bank stock returns. The resid. $(-1)^{2}$ represents the ARCH parameter and the GARCH (-1) denotes the GARCH parameter. The sum of both $\alpha 1$ and $b$ coefficients that results in large positive less than 1.0 fulfills the condition of non-negativity and both parameters are statistically significant at $1 \%$ level except for AmBank stock return. These findings show that there is a prolonged and continued existence of volatility shocks and the volatility reaction decomposes at a moderate pace. Putting in other words, the findings signify that the impact of current shock remains in the forecast of variance in many periods in the future. In addition, the GARCH coefficients are significantly larger than the ARCH coefficients. This proves that the volatility of bank portfolio and individual bank stock returns are more sensitive to their respective own lagged values than to the new shocks. This indirectly implies that the impacts of prior period's forecast variance are more constant or continual 
INTERNATIONAL JOURNAL OF ACADEMIC RESEARCH IN ACCOUNTING, FINANCE AND MANAGEMENT SCIENCES

Vol. 11, No. 1, 2021, E-ISSN: 2225-8329 @ 2021 HRMARS

on the conditional bank stock returns. Conclusively, the greater and statistically significant of GARCH $B$ signifies the robust attestation of prior shocks whilst the slight and statistically significant of $A R C H$ $\alpha 1$ provides weak evidence for the existence of the prior period's surprises or shocks on the bank stock return volatility.

\section{Conclusion}

This paper examines the banks stock returns sensitivity to the changes in the market, foreign exchange and interest rates returns. The OLS estimation reveals that the bank portfolio and individual banks stocks returns are more sensitive towards the changes in market returns than to the changes in foreign exchange and interest rates returns. This implies the market or economic-wide risk factor has more impact on the stock prices that ultimately affects the banks stock returns. The GARCH $(1,1)$ estimation proves the presence of time-varying conditional volatility in the banks stock returns. The estimation also reveals the continual presence of volatility surprises, where the volatility response decomposes at a moderate rate. The GARCH parameter, which is significantly greater than the ARCH parameter evidences the volatility of bank stock returns, is more sensitive to its own lagged values than to the new surprises.

The results of this paper are crucial to the individual bank management and the banking industry authority, namely Bank Negara Malaysia (BNM). The bank management must closely monitor and take into account the changes in the market index, interest rate and exchange rate in their risk management policy. In addition, the results of study could be beneficial to the bank management in outlining the hedging strategy through derivative market against the risk exposures particularly caused by the changes in interest rate and exchange rate. The BNM, as the policy maker, must take into consideration the banking sector's condition when formulating the monetary policies specifically related to interest rate and exchange rate. This is pivotal as the survival of the banking sector will determine the economic survival of a country.

Other than that, the stock market investors and portfolio managers will also benefit from this study. The findings would assist them in setting trading strategy besides making buy and sell decisions. The findings could also become an important basis for them to construct the investment portfolio by considering banking stocks as one of the investment alternatives. The stock market operator, namely Bursa Malaysia (BM) and the stock market regulator, namely the Securities Commission (SC) could further enhance and monitor the performance of stock market guided by the findings of this study.

The findings could contribute significantly towards the betterment of banks stocks performance and prediction in the future besides guiding the investors in their investment decision making. The policy makers could take this as a signal in formulating the policies pertaining to the economic variables. The findings are hopefully contributing towards the enrichment of existing literature particularly for the Malaysian context. For future research, it is recommended to extend the study by testing the GARCH $(1,1)$ model to check on the volatility of the bank stock returns in relation to volatility of the economic variables. The sample could be extended by including the foreign banks that are located in Malaysia for further confirmation of the results.

\section{Acknowledgment}

We would like to thank the Bahagian Penyelidikan, Jaringan Industri \& Alumni (BPJIA) of UiTM Johor Branch for their supports in completing this study. 
INTERNATIONAL JOURNAL OF ACADEMIC RESEARCH IN ACCOUNTING, FINANCE AND

MANAGEMENT SCIENCES

Vol. 11, No. 1, 2021, E-ISSN: 2225-8329 @ 2021 HRMARS

\section{References}

Aloui, M., \& Jarboui, A. (2016). Market, interest rate and exchange rate risk effects on financial sector returns during the financial crisis: AGARCH-M approach. Cogent Economics and Finance, 4(1), 2332-2039.

https://doi.org/10.1080/23322039.2015.1125332

Aloui, M., \& Jarboui, A. (2013). The impact of interest rate on exchange rate volatility on bank's return and volatility: Evidence from Tunisia. International Journal of Information, Business and Management, 5, 73-90.

Benink, H. A., \& Wolff, C. C. P. (2000). Survey data and the interest rate sensitivity of US bank stock returns. Economic Notes by Banca Monte dei Paschi di Siena SpA, 29 (2), 201-213. https://doi.org/10.1111/1468-0300.00030

Choi, J. J., Elyasiani, E., \& Kopecky, K. J. (1992). The sensitivity of bank stock returns to market, interest and exchange rate risks. Journal of Banking and Finance, 16(1), 983-1004. https://doi.org/10.1016/0378-4266(92)90036-Y

Denenis, E., \& Staikouras, S. K. (1998). Interest rate changes and common stock returns of financial institutions: Evidence from the UK. The European Journal of Finance, 4(2), 113-127. https://doi.org/10.1080/135184798337344

Elyasiani, E., \& Mansur, I. (2004). Bank stock return sensitivities to the long-term and short-term interest rates: A multivariate GARCH approach. Managerial Finance, 30 (9), 32-55. https://doi.org/10.1108/03074350410769263

Elyasiani, E., \& Mansur, I. (2005). The association between market and exchange rate risk and accounting variables: A GARCH model of the Japanese banking institution. Review of Quantitative Finance and Accounting, 25, 183-206. https://doi.org/10.1007/s11156-005-42486

Flannery, M. J. (1981). Market interest rates and commercial bank profitability: An empirical investigation. The Journal of Finance, 36(5), 1085-1101. https://doi.org/10.1111/j.15406261.1981.tb01078.x

Fraser, D. R., Madura, J., \& Weigand, R. A. (2002). Sources of bank interest rate risk. The Financial Review, 37, 351-368. https://doi.org/10.1111/0732-8516.00002

Hooy, C. W., Tan, H. B., \& Nassir, A. M. (2004). Risk sensitivity of bank stocks in Malaysia: Empirical evidence across the Asian financial crisis. Asian Economic Journal, 18 (3), 261-276. https://doi.org/10.1111/j.1467-8381.2004.00192.x

Jeanchutima, S., \& Tangjitprom, N. (2015, January 5-8). Bank stock returns sensitivity to interest rate changes in Thailand. XIV International Business and Economy Conference, Bangkok, Thailand. http://dx.doi.org/10.2139/ssrn.2550005

Joseph, N. L., \& Vezos, P. (2006). The sensitivity of US banks' stock returns to interest rate and exchange rate changes. Managerial Finance, $32 \quad$ (2), 182 - 199. https://doi.org/10.1108/0307435061064193

Kasman, S., Vardar, G., \& Tunc, G. (2011). The impact of interest rate and exchange rate volatility on banks' stock returns and volatility: Evidence from Turkey. Economic Modelling, 28, 1328-1334. https://doi.org/10.1016/j.econmod.2011.01.015

Khan, M. R., \& Mahmood, Z. (2013). Interest rate sensitivity and stock returns. Business Review, 8 (1), 20-33. 
INTERNATIONAL JOURNAL OF ACADEMIC RESEARCH IN ACCOUNTING, FINANCE AND

MANAGEMENT SCIENCES

Vol. 11, No. 1, 2021, E-ISSN: 2225-8329 @ 2021 HRMARS

Khan, W. A., \& Sattar, A. (2014). Impact of interest rate changes on the profitability of four major commercial banks in Pakistan. International Journal of Accounting and Financial Reporting, 4(1), 142-154. http://dx.doi.org/10.5296/ijafr.v4i1.5630

Lee, T. M., Kuo, S. H., \& Lee, M. L. (2018). Real estate exposure of US banking industry stock returns: Evidence from commercial and resident market. International Journal of Strategic Property Management, 18 (1), 12-23.

https://doi.org/10.3846/ijspm.2018.319

Martina, S., Sadalia, I., \& Bukit, R. (2019). The effect of quick ratio, debt to equity ratio, earning per share, price to book value and return on equity on stock return with money supply as moderated variables (study of banking companies listed on Indonesia Stock Exchange period 2008 - 2017). Journal of Public Budgeting, Accounting and Finance, 2 (3), 1-10.

Mouna, A., \& Anis, J. (2016). Market, interest rate, exchange rate risk effect on financial stock return during financial crisis. Cogent Economics Finance, 4(1), 1-16. https://doi.org/10.1080/23322039.2015.1125332

Priti, V. (2016). The impact of exchange rates and interest rates on bank stock return: Evidence from US banks. Studies in Business and Economics, 11(1), 124-139. https://doi.org/10.1515/sbe2016-0011

Rafiq, M. Z., Jun, J. C., Naseem, S., \& Mohsin, M. (2019). Impact of market risk, interest rate, exchange rate on banks stock return: Evidence from listed banks of Pakistan. Amazonia Investiga, 8 (21) 667-673.

Ryan, S. K., \& Worthington, A. C. (2004). Market, interest rate and foreign exchange rate risk in Australian banking: A GARCH-M approach. International Journal of Applied Business and Economic Research, 2, 81-103.

Saporoschenko, A. (2002). The sensitivity of Japanese bank stock returns to economic factors: An examination of asset/liability differences and main bank status. Global Finance Journal, 13, 253-270. https://doi.org/10.1016/S1044-0283(02)00043-1

Shamsuddin, A. F. M. (2009). Interest rate and foreign exchange risk exposures of Australian banks: A note. International Journal of Banking \& Finance, 6 (2), 129-138.

Tripathi, V., \& Ghosh, R. (2012). Interest rate sensitivity of banking stock returns in India. International Journal of Financial Management, 2(4), 10-20. 